\title{
Cell Type-Specific Long-Term Plasticity at Glutamatergic Synapses onto Hippocampal Interneurons Expressing either Parvalbumin or $\mathrm{CB}_{1}$ Cannabinoid Receptor
}

\author{
Wiebke Nissen, ${ }^{1}$ Andras Szabo, ${ }^{1}$ Jozsef Somogyi, ${ }^{2}$ Peter Somogyi, ${ }^{2}$ and Karri P. Lamsa ${ }^{1}$ \\ ${ }^{1}$ Department of Pharmacology, Oxford University, Oxford OX1 3QT, United Kingdom, and ${ }^{2}$ Medical Research Council Anatomical Neuropharmacology \\ Unit, Oxford University, Oxford OX1 3TH, United Kingdom
}

\begin{abstract}
Different GABAergic interneuron types have specific roles in hippocampal function, and anatomical as well as physiological features vary greatly between interneuron classes. Long-term plasticity of interneurons has mostly been studied in unidentified GABAergic cells and is known to be very heterogeneous. Here we tested whether cell type-specific plasticity properties in distinct GABAergic interneuron types might underlie this heterogeneity. We show that long-term potentiation (LTP) and depression (LTD), two common forms of synaptic plasticity, are expressed in a highly cell type-specific manner at glutamatergic synapses onto hippocampal GABAergic neurons. Both LTP and LTD are generated in interneurons expressing parvalbumin $(\mathrm{PV}+)$, whereas interneurons with similar axon distributions but expressing cannabinoid receptor-1 show no lasting plasticity in response to the same protocol. In addition, LTP or LTD occurs in PV + interneurons with different efferent target domains. Perisomatic-targeting PV + basket and axo-axonic interneurons express LTP, whereas glutamatergic synapses onto PV + bistratified cells display LTD. Both LTP and LTD are pathway specific, independent of NMDA receptors, and occur at synapses with calcium-permeable (CP) AMPA receptors. Plasticity in interneurons with CP-AMPA receptors strongly modulates disynaptic GABAergic transmission onto CA1 pyramidal cells. We propose that long-term plasticity adjusts the synaptic strength between pyramidal cells and interneurons in a cell type-specific manner and, in the defined CA1 interneurons, shifts the spatial pattern of inhibitory weight from pyramidal cell dendrites to the perisomatic region.
\end{abstract}

\section{Introduction}

Synapses between cortical excitatory principal cells show relatively stereotypical activity-induced plasticity and may express either long-term potentiation (LTP) or long-term depression (LTD) depending on glutamate NMDA receptors (NMDARs). Concomitant with LTP in hippocampal pyramidal cells, the strength of local inhibition is often altered (Kullmann and Lamsa, 2007; McBain, 2008; Pelletier and Lacaille, 2008). Parallel modulation of inhibition is likely to be required to balance changes in the network excitability caused by plasticity between principal cells (Kullmann and Lamsa, 2007), as well as to maintain fidelity, threshold, and gain of pyramidal cell responses to their excitatory inputs (Lamsa et al., 2005; Carvalho and Buonomano, 2009).

\footnotetext{
Received July 16, 2009; revised 0ct. 12, 2009; accepted Nov. 22, 2009

This work was supported by the Wellcome Trust, the United Kingdom Medical Research Council, and the German Academic Exchange Service (Deutscher Akademischer Austausch Dienst). We are grateful to Tamas Bellak, Wendy Tynan, Kristina Detzner, and David Roberts for expert technical assistance. We thank Drs. Colin Akerman, Marlene Bartos, Marco Capogna, Jozsef Csicsvari, Dimitri Kullmann, Peter Magill, and Trevor Sharp for comments on this manuscript. We thank the following scientists for their generous gifts of antibodies: K. G. Baimbridge (antibody to parvalbumin), A. Buchan (to somatostatin), T. Gorcs (to VIP), A. Varro (to pro-CCK), M. Watanabe (to $\mathrm{CB}_{1}$ receptor, VGluT3), and S. El Mestikawy (to VGluT3). Antibodies 9303 and 55 raised against CCK and VIP, respectively, were provided by the Center for Ulcer Research/Digestive Diseases Research Center, Antibody/Radioimmunoassay Core (National Institutes of Health Grant DK41301).

Correspondence should be addressed to K. Lamsa, Department of Pharmacology, Oxford University, Mansfield Road, 0xford 0X130T, UK. E-mail: karri.lamsa@pharm.ox.ac.uk.

J. Somogyi's present address: JSW Life Sciences, Parkring 12, Grambach A-8074, Austria.

D01:10.1523/JNEUROSCI.3481-09.2010

Copyright $\odot 2010$ the authors $\quad 0270-6474 / 10 / 301337-11 \$ 15.00 / 0$
}

However, plasticity reported in GABAergic interneurons is highly heterogeneous and varies between hippocampal areas and layers (McMahon and Kauer, 1997; Cowan et al., 1998; Alle et al., 2001; Perez et al., 2001; Lei and McBain, 2004; Lamsa et al., 2005, 2007; Galván et al., 2008), possibly reflecting the high diversity of GABAergic cells in the hippocampus (Kullmann and Lamsa, 2007; McBain, 2008). Cell type-specific firing patterns of many interneurons in vivo suggest that distinct GABAergic cell types have highly specified roles in the hippocampal function (Klausberger et al., 2003, 2005). Excitatory glutamatergic synapses onto many hippocampal interneurons have calcium-permeable (CP) AMPA receptors (AMPARs), and these synapses often express NMDA receptor-independent LTP or LTD (Laezza et al., 1999; Perez et al., 2001; Laezza and Dingledine, 2004; Lei and McBain, 2004; Lamsa et al., 2007; Oren et al., 2009). Afferent stimulation of glutamatergic pathways, which elicits LTP in principal cells in the hippocampal CA1 or dentate gyrus, can induce parallel potentiation of GABAergic transmission (Buzsáki and Eidelberg, 1982; Kairiss et al., 1987; Lapointe et al., 2004; Lamsa et al., 2005). It has been suggested that this might result from LTP of excitatory glutamatergic synapses driving a subpopulation of local inhibitory interneurons (Kullmann and Lamsa, 2007; Pelletier and Lacaille, 2008). Equally, afferent stimulation of hippocampal mossy fibers can elicit either LTP or LTD in CA3 inhibitory cells in a layerspecific manner (Maccaferri et al., 1998; Lei and McBain, 2004; Galván et al., 2008; McBain, 2008), but each hippocampal layer may contain several types of interneurons, as defined by their 
neurochemical markers and the pyramidal cell membrane domains that their axons target. To understand the nature and functional significance of heterogeneous interneuron plasticity in the hippocampus, it is therefore important to identify the interneurons studied in terms of their axonal projections and molecular expression profiles.

Here we test how consistent long-term plasticity is across five common interneuron types innervating different domains of pyramidal cells in the hippocampal CA1 area. We hypothesized that plasticity properties might systematically vary between individual GABAergic interneuron types. In the CA1 area, interneurons immunopositive for parvalbumin $(\mathrm{PV}+)$ or cannabinoid receptor 1 $\left(\mathrm{CB}_{1} \mathrm{R}+\right)$ collectively target the whole postsynaptic surface of local pyramidal cells, but individual cell types preferentially innervate one or more specific membrane domains of their targets. We demonstrate that there are cell type-specific rules of plasticity that emphasize distinct roles of interneurons in hippocampal function.

\section{Materials and Methods}

\section{Hippocampal slice preparation}

Three- to 4-week-old male Sprague Dawley rats were killed according to the Animals (Scientific Procedures) Act 1986, and transverse hippocampal slices (350 $\mu \mathrm{m}$ thickness) were prepared as described by Oren et al. (2009) (supplemental Methods, available at www.jneurosci.org as supplemental material). Hippocampal slices were placed in a recording chamber (Luigs \& Neumann) mounted on the stage of an upright microscope (Olympus BX51WI), where they were held under a nylon mesh grid and superfused at $3-5 \mathrm{ml} / \mathrm{min}$ with artificial CSF at $31-33^{\circ} \mathrm{C}$. Slices were visualized using a $20 \times$ immersion objective with $2-4 \times$ zoom and infrared differential interference contrast (DIC) optics. A cut was made between CA1 and CA3 to prevent propagation of recurrent excitation from the CA3. The perfusion medium contained the following (in $\mathrm{mM}$ ): $119 \mathrm{NaCl}, 2.5 \mathrm{KCl}, 2.5 \mathrm{CaCl}_{2}, 1.3 \mathrm{MgSO}_{4}, 1.25 \mathrm{NaH}_{2} \mathrm{PO}_{4}, 25 \mathrm{NaHCO}_{3}$, and 11 glucose, final $\mathrm{pH} 7.4$ (equilibrated with $95 \% \mathrm{O}_{2} / 5 \% \mathrm{CO}_{2}$ ). Glutamate NMDARs were blocked with DL-APV $(100 \mu \mathrm{M})$ unless stated otherwise. The GABA receptor blockers picrotoxin (PiTX) $(100 \mu \mathrm{M})$ and CGP55845 [(2S)-3-[(1S)-1-(3,4-dichlorophenyl) ethyl]amino-2hydroxypropyl)(phenylmethyl)phosphinic acid] $(1 \mu \mathrm{M})$ were added to the solution for all experiments except those for recording IPSCs (see Figs. 5, 6) (supplemental Figs. S3, S4, available at www.jneurosci.org as supplemental material). In experiments with cannabinoid receptor type 1 antagonist AM-251 [N-1-(2,4-dichlorophenyl)-5-(4-iodophenyl)-4methyl- $\mathrm{N}$-1-piperidinyl- $1 \mathrm{H}$-pyrazole-3-carboxamide] (5-10 $\mu \mathrm{M})$, slices were incubated with the drug for at least $1 \mathrm{~h}$ before recording, and the drug was present in the perfusion solution. Glutamate receptor antagonists philanthotoxin-433 (PhTx) $(10 \mu \mathrm{M})$ and NBQX $(10 \mu \mathrm{M})$ were applied via perfusion. Chemicals were purchased from Sigma-Aldrich and drugs from Tocris Bioscience or Ascent Scientific.

\section{Electrophysiological recordings}

Perforated patch. For additional details, see supplemental Methods (available at www.jneurosci.org as supplemental material). Somatic perforated-patch recordings were made from neurons close to or inside CA1 stratum (str.) pyramidale using pipettes containing gramicidin (50$200 \mu \mathrm{g} / \mathrm{ml}$ ). Electrodes were made from borosilicate glass capillaries. Pipette resistance was $8-15 \mathrm{M} \Omega$. Filling solution contained the following (in mM): $145 \mathrm{~K}$-gluconate, $8 \mathrm{NaCl}, 20-25 \mathrm{~K}$-HEPES, $0.2 \mathrm{EGTA}$, and 5 QX-314 Br [N-(2,6-dimethylphenylcarbamoylmethyl)triethylammonium bromide], pH 7.2 (osmolarity, $295 \mathrm{mOsm} / \mathrm{L}$ ). The electrode tip was filled with gramicidin-free solution. Recordings were started when series resistance was below $150 \mathrm{M} \Omega$. Series resistance was continuously monitored but not recorded.

Repatch. After completion of perforated patch recordings, the pipette was slowly retracted under infrared DIC observation. Once the pipette detached from the cell, it was rapidly withdrawn from the slice. Next, the same cell was approached with a new pipette and repatched in whole-cell configuration. Infrared images of the cell at different magnification were obtained with a CCD camera during perforated patch recording and compared in whole-cell recordings to verify that the same cell was repatched (supplemental Fig. 1, available at www.jneurosci.org as supplemental material) (Lamsa et al., 2005, 2007; Oren et al., 2009). Voltage-clamp recording of EPSCs was performed in repatched cells only if access resistance was $<20 \mathrm{M} \Omega$.

Whole cell. For additional details, see supplemental Methods (available at www.jneurosci.org as supplemental material). The whole-cell recordings were made with a solution containing the following (in $\mathrm{mM}$ ): 145 CsCl, 20 HEPES, 0.2 Cs-EGTA, $8 \mathrm{NaCl}, 2 \mathrm{Mg}$-ATP, $0.3 \mathrm{GTP}$, and 5 QX-314 Br, pH 7.2 (295 mOsm). In some experiments, 145 mм Csmethanesulphonate was used instead of $\mathrm{CsCl}$. Spermine tetrahydrochloride $(0.5 \mathrm{~mm}$; Tocris Bioscience) was included in the filling solution to maintain polyamine-mediated rectification of AMPA/kainate receptors during whole-cell recording. In addition, Neurobiotin $(0.2-0.5 \%$; Vector Laboratories) or biocytin (0.5\%; Sigma-Aldrich) was included in the solution to enable post hoc anatomical analysis. Electrode input resistance for whole-cell recordings was 4-6 M $\Omega$.

Electrical stimulation. For additional details, see supplemental Methods (available at www.jneurosci.org as supplemental material). Monosynaptic EPSPs or EPSCs were evoked by alternately stimulating (50-100 $\mu \mathrm{s})$ in the str. oriens/alveus in area CA1 with $15 \mathrm{~s}$ interevent interval via two concentric bipolar electrodes, connected to constant-current isolated stimulators. In some experiments, the stimulation electrode for control pathway was positioned in str. radiatum (supplemental Tables 1, 2, available at www.jneurosci.org as supplemental material). Evoked EPSPs were recorded from the resting membrane potential or in some experiments during a brief $(500 \mathrm{~ms})$ hyperpolarizing step $(5-10 \mathrm{mV})$ to avoid action potential generation. In whole-cell recordings, EPSC current-voltage relationships were estimated over a postsynaptic membrane potential range from -90 to $+60 \mathrm{mV}$ using $1 \mathrm{~s}$ steps in voltage-clamp mode. The EPSC rectification index (RI) was obtained by dividing the amplitude of the EPSC recorded at $+60 \mathrm{mV}$ by that measured at -60 $\mathrm{mV}$. A Multiclamp $700 \mathrm{~B}$ amplifier was used for recording. In all recordings, data were low-pass filtered $(4-5 \mathrm{kHz})$ and acquired at $10-20 \mathrm{kHz}$ on a personal computer for offline analysis. Data were analyzed using LabView and pClamp 10. Disynaptic IPSCs were evoked by stimulation in str. oriens/alveus and voltage clamping the postsynaptic cell between 0 and $+10 \mathrm{mV}$ (Cs-methanesulphonatecontaining filling solution was used). Maximum disynaptic IPSC was screened by increasing stimulation intensity voltage using fixed duration $(100-150 \mu \mathrm{s})$. Submaximal amplitude IPSCs were evoked by shortening the stimulation duration (up to $25 \mu \mathrm{s}$ ).

Statistics. Data are shown as mean \pm SE. Data on postsynaptic potentials/currents were baseline normalized within each pathway and analyzed with Student's paired $t$ test. Within each cell, the change in the initial slope (3-5 ms from onset) of the paired pathway was compared with that of the control pathway with an unpaired $t$ test.

\section{Anatomical analysis}

Tissue processing. For additional details, see supplemental Methods (available at www.jneurosci.org as supplemental material). Neurons were filled with Neurobiotin (Vector Laboratories) or biocytin (Sigma) during whole-cell recordings, fixed, and examined as described by Oren et al. (2009). For illustration, selected cells were digitally photographed from one or two $70-\mu \mathrm{m}$-thick sections using structured illumination microscopy (AxioImager ApoTome, Carl Zeiss AxioImager.Z1) with a Carl Zeiss 38HE filter, $40 \times$ oil-immersion objective and AxioVision Release 4.7.1 software. Images were constructed from $Z$-stacks using NIH ImageJ 1.42 software and inverted to show the cell on a white background; NeuronJ program was used for neurite tracing at a preset line thickness and quantification. Dendrites were manually selected from microscopic examination and are shown in a color different from the axon. Epifluorescent images were taken with the Carl Zeiss AxioImager.Z1 microscope (Carl Zeiss HE38 filter, $40 \times$ or $63 \times$ oil-immersion objective) using AxioVision software, and digital micrographs were constructed from $Z$-stacks with NIH ImageJ software. Micrographs were not 
manipulated selectively; only brightness and contrast of the whole stacked image was adjusted.

Immunohistochemistry. For additional details, see supplemental Methods (available at www.jneurosci.org as supplemental material). Sections were blocked in normal horse serum (Vector Laboratories) for $1 \mathrm{~h}$ and incubated in mixtures of appropriate primary antibodies for $48 \mathrm{~h}$ at $4^{\circ} \mathrm{C}$. A complete list of primary antibodies, their species, dilution, source, and specificity references is given in supplemental Table 3 (available at www.jneurosci.org as supplemental material). When fluorescence was not detectable in the relevant area of the section in which similar parts of other unfilled cells were immunopositive, cells were considered immunonegative. If a decision about immunoreactivity could not be clearly made because the cell appeared to be negative but the immunoreactivity in unrecorded cells of the slice was low or mostly absent, then the immunoreaction test does not inform about the presence or absence of the molecule in that specific cell. Furthermore, in cases of low immunoreactivity levels, when a conclusion could not be reached by several investigators, the test was considered inconclusive [indicated as reacted but not tested ("nt") in supplemental Tables 1, 2, available at www.jneurosci.org as supplemental material].

Electron microscopy. Sections from two putative axo-axonic cells were prepared for electron microscopic analysis (supplemental Table 1 , available at www.jneurosci.org as supplemental material). After fixation and resectioning of slices (as above), selected sections were washed in $0.1 \mathrm{M}$ phosphate buffer (PB) and then stored in $0.05 \%$ sodium azide with $0.1 \mathrm{M} \mathrm{PB}$. After cryoprotection with sucrose and freeze-thaw to enhance penetration of reagents, the cells were revealed with HRP reaction [ABC Elite kit (Vector Laboratories); 0.05\% $\mathrm{DAB}$ (Sigma) and $0.01 \% \mathrm{H}_{2} \mathrm{O}_{2}$ ). The sections were treated with $1 \%$ $\mathrm{OsO}_{4}$ (in phosphate buffer; TAAB Laboratory Equipment) and 1\% aqueous uranyl acetate, dehydrated, and embedded in epoxy resin (Durcupan; Fluka). The axons were examined for the identity of postsynaptic targets without lead staining (Klausberger et al., 2003).

\section{Results}

\section{Cell type-specific LTP in CA1 perisomatic-targeting interneurons}

We studied long-term plasticity in glutamatergic afferents onto five different GABAergic interneuron types or groups in the hippocampal CA1 area, as defined by their axonal projections and molecular expression profiles (Klausberger and Somogyi, 2008). We patched putative interneurons inside or in the vicinity of str. pyramidale in the CA1 area of hippocampal slices. Perforated patch recording was used to minimize disruption of intracellular postsynaptic content of interneurons (Kullmann and Lamsa, 2007). Interneurons were then repatched with a new pipette in whole-cell mode, studied in voltage clamp, and filled with biocytin for post hoc anatomical identification (Lamsa et al., 2007; Oren et al., 2009). Cells were identified on the basis of axonal pattern and neurochemical marker expression. Briefly, cell types were as follows: axo-axonic cells innervating mainly or exclusively the axon initial segment of pyramidal cells; basket cells innervating somata and proximal dendrites as predicted from the concentration of their axon in str. pyramidale and expressing either $\mathrm{PV}$ or $\mathrm{CB}_{1} \mathrm{R}$; and bistratified cells innervating mainly dendrites in str. radiatum and oriens and expressing PV, neuropeptide Y (NPY), and/or somatostatin (Halasy et al., 1996; Losonczy et al., 2002; Pawelzik et al., 2002; Klausberger et al., 2004; Baude et al., 2007). The fifth group of interneurons included several cell types in terms of synaptic targets, as predicted from the absence of axon concentration to str. pyramidale and, for brevity, will be called "non-basket cell $\mathrm{CB}_{1} \mathrm{R}$-expressing cell type" because, in slice preparations, often insufficient axon is revealed for accurate identification (Klausberger and Somogyi, 2008). Cells classified as $\mathrm{CB}_{1} \mathrm{R}+$ non-basket cells had their soma in either str. radiatum $(n=11)$ or str. oriens $(n=3)$. They presented radially or diagonally oriented dendrites in strata oriens and radiatum, sometimes with small dendritic tufts into str. lacunosum moleculare, and large axon arbors in strata oriens and/or radiatum, hardly ever crossing the border to str. lacunosum moleculare. The proportion of innervation to str. oriens or str. radiatum differed between individual cells (for examples, see Fig. $2 D, E$ ). Long axon collaterals traveling across strata oriens and radiatum were characteristic of most $\mathrm{CB}_{1} \mathrm{R}+$ non-basket cells. Others were more reminiscent of bistratified cells with denser axon clusters above and below str. pyramidale, but the pyramidal layer itself always had sparse innervation in contrast to typical basket cells. Only cells that fit the criteria for one of the categories above were included in this study. Data for identification of all interneurons studied are presented in supplemental Tables 1 and 2 (available at www. jneurosci.org as supplemental material).

We elicited EPSPs by alternately stimulating two electrodes in different locations in str. oriens/alveus to activate pyramidal cell axons (see Materials and Methods). GABA receptors were blocked by PiTX $(100 \mu \mathrm{M})$ and CGP55845 $(1 \mu \mathrm{M})$, and glutamate NMDARs were blocked with DL-APV $(100 \mu \mathrm{M})$. After a baseline period of at least $10 \mathrm{~min}$, high-frequency stimulation (HFS) (100 $\mathrm{Hz}$ for $1 \mathrm{~s}$, delivered twice, $20 \mathrm{~s}$ interval) was delivered to one pathway, whereas the other pathway served as a control. Unlike the long-term plasticity in pyramidal cells, LTP and LTD in many hippocampal interneurons is NMDAR independent and involves CP-AMPARs (Laezza et al., 1999; Lamsa et al., 2007; Oren et al., 2009). Postsynaptic somatic potential was voltage clamped to $-70 \mathrm{mV}$ (or more negative down to $-90 \mathrm{mV}$ ) during HFS to maximize conductance of CP-AMPAR (Geiger et al., 1995) (supplemental Fig. 1, available at www.jneurosci.org as supplemental material). After the HFS, EPSPs were recorded for at least $20 \mathrm{~min}$ before cells were repatched (in three cells, LTP was followed up to $30 \mathrm{~min}$ ). Analysis of EPSPs was focused on initial slope of EPSPs (3-5 ms from onset) to avoid contamination by polysynaptic EPSPs (Maccaferri and McBain, 1996; Lamsa et al., 2005). The high-frequency stimulation did not cause long-lasting changes in the resting membrane potential of the interneurons (supplemental Fig. 1, available at www.jneurosci.org as supplemental material) (Ross and Soltesz, 2001).

Visualization of the cells (see Materials and Methods) revealed that LTP was elicited in 7 of 14 interneurons whose axon targeted specifically the perisomatic domain of CA1 pyramidal cells. LTP was defined as potentiation of EPSP initial slope at least to $125 \%$ of baseline (tested with paired $t$ test) and specific to the pathway (significant difference to control pathway, tested with unpaired $t$ test). In cells with significant potentiation and pathway specificity, EPSP in the tetanized pathway increased to $156 \pm 8 \%(p<$ $0.005, n=7,20$ min after HFS), whereas EPSP in the control pathway did not change $(102 \pm 6 \%)$ (Fig. $1 A-C)$. Four of the interneurons with LTP were identified as axo-axonic cells, based on their axonal patterns showing radial bouton rows that follow axon initial segments of pyramidal cells (Somogyi et al., 1985). Two cells randomly selected were confirmed by electron microscopy to innervate axon initial segments, and two were confirmed as expressing PV (Klausberger et al., 2003). The three other cells showing LTP and targeting pyramidal cells perisomatically were identified as basket cells. Immunohistochemical testing showed that these basket cells were all positive for $\mathrm{PV}$ and negative for $\mathrm{CB}_{1} \mathrm{R}$ (Fig. $1 D, E$ ) (supplemental Table 1, available at www.jneurosci.org as supplemental material). One additional axo-axonic cell failed to show LTP. Average potentiation of EPSP in all eight PV+ 
A
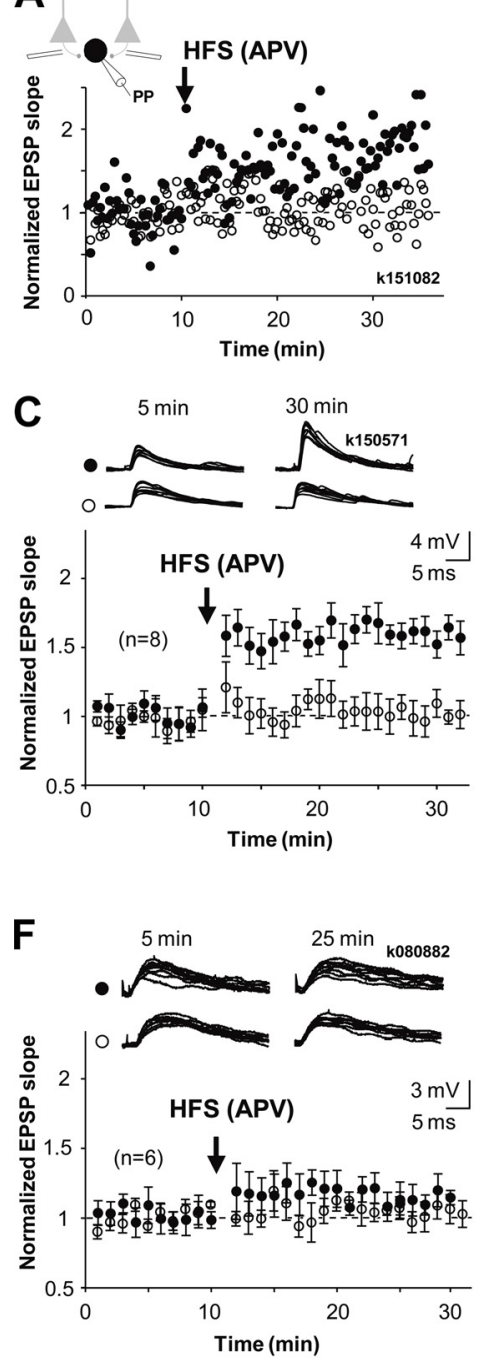

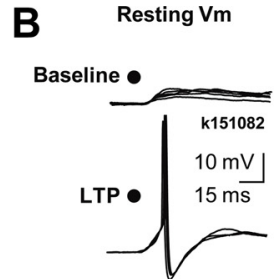

Hyperpolarized by $10 \mathrm{mV}$ $5 \mathrm{~min} \quad 30 \mathrm{~min}$
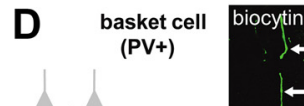
(PV+)
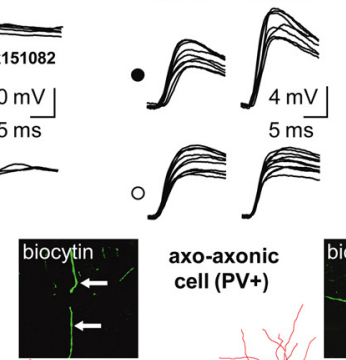

axo-axonic cell (PV+)
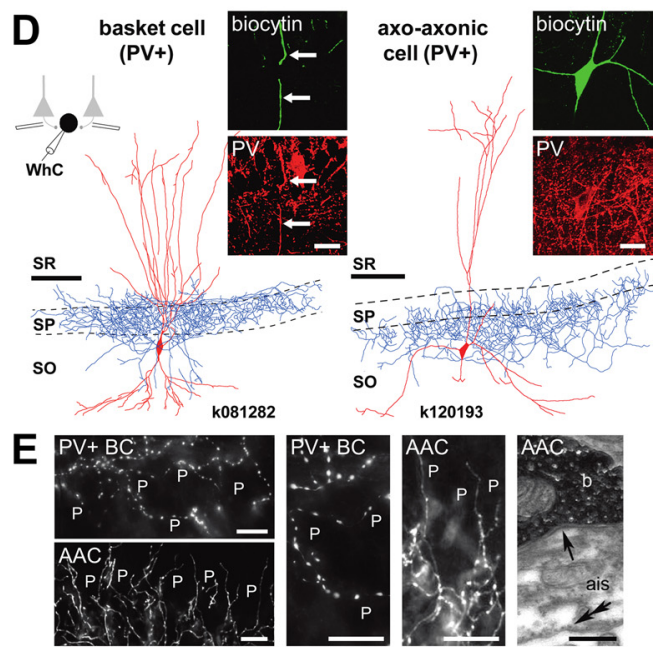

$\mathbf{G}$ basket cell (CB1R+)
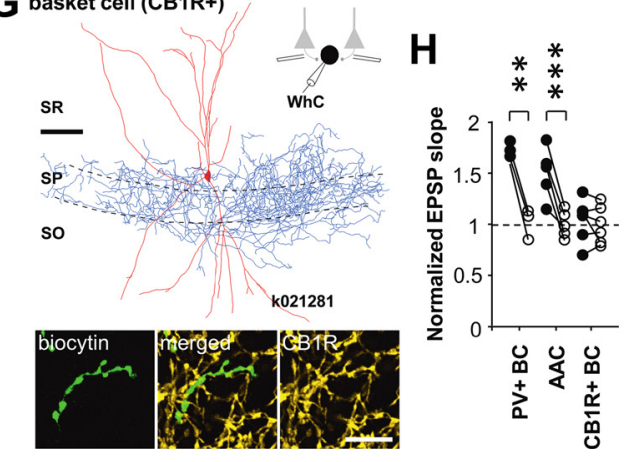

Figure 1. Cell type-specific LTP in interneurons innervating the perisomatic domain of pyramidal cells. $\boldsymbol{A}-\mathbf{G}, \mathrm{LTP}$ is generated in $\mathrm{PV}+$ basket cells and axo-axonic cells but not in basket cells expressing $C B_{1} R$. Recordings were made in perforated patch; cells were repatched in whole cell for post hoc identification using biocytin labeling. $A$, Pathway-specific LTP in a PV + basket cell. Two glutamatergic afferent pathways were stimulated with electrodes in str. oriens/alveus. After baseline period, $\mathrm{HFS}(100 \mathrm{~Hz}, 1 \mathrm{~s}, \mathrm{tw} 0$ times) was delivered to one pathway (filled symbols), whereas the other pathway served as control (open symbols). Schematic shows experimental design during perforated patch (PP) recording. Timing of HFS is indicated by an arrow. During HFS, the postsynaptic cell was voltage clamped to $-70 \mathrm{mV}$. Potentiation of EPSP lasted at least $25 \mathrm{~min}$ and was restricted to the stimulated pathway. $\boldsymbol{B}$, Consecutive EPSPs in the basket cell in $\boldsymbol{A}$ during baseline and $20 \mathrm{~min}$ after the HFS. Left, EPSP at resting membrane potential (resting Vm) triggered action potentials after LTP. To avoid action potentials, EPSPs were recorded during a hyperpolarizing step $(-10 \mathrm{mV})$ throughout the experiment. Symbols indicate tetanized and control pathways as in $\boldsymbol{A}$. C, EPSP slope mean \pm SE in eight identified perisomatic-targeting PV + interneurons. Data include three PV + basket cells and five axo-axonic cells, and symbols indicate tetanized and control pathway as in $\boldsymbol{A}$. Top, Consecutive EPSPs in the two pathways during baseline and 20 min after the HFS. D, Digital visualization of PV + basket cell k081282 (left; dendrites in red from two 70 - $\mu \mathrm{m}$-thick sections, axon in blue, from one section) and axo-axonic cell k120193 (right, one section) recorded in whole cell (WhC). Images produced from confocal microscopic image stacks. Scale bar, $100 \mu \mathrm{m}$. Insets, Immunofluorescence micrographs of the labeled cells demonstrating the expression of PV in the dendrites (indicated by arrow) and soma of the cells. Laser confocal microscope images; biocytin is in green and PV is in red. Scale bar, $20 \mu \mathrm{m}$. SR, str. radiatum; SP, str. pyramidale; SO, str. oriens. $\boldsymbol{E}$, Distinct axonal patterns of a basket cell and an axo-axonic cell within the pyramidal cell layer. Left, Epifluorescent micrographs of a PV + basket cell (PV + BC, k151082) showing undulating bouton laden axon collaterals, often running parallel with the pyramidal cell layer, among pyramidal cells (P), and an ax0-axonic cell (AAC, k100871), showing their characteristic radial bouton bundles. The axo-axonic bouton rows follow axon initial segments of pyramidal cells $(P)$ toward str. oriens. Scale bar, $20 \mu \mathrm{m}$. Middle, Higher-magnification epifluorescent micrographs of the same PV + basket cell (PV $+B C$, middle left) and axo-axonic cell ( $A A C$, middle right). Scale bar, $20 \mu \mathrm{m}$. Right, Electron micrograph showing a synapse (arrow) received by an axon initial segment (ais) from a bouton (b) of axo-axonic cell k100871. The bouton is identified by the electron opaque HRP end product and the ais by the membrane undercoating (double arrow). Scale bar, $0.25 \mu \mathrm{m}$. $F$, EPSPs in basket cells expressing $\mathrm{CB}_{1} R$ do not show lasting plasticity. EPSP slope mean \pm SE in six basket cells tested for LTP and plotted as above. Top, EPSPs during baseline and 15 min after the HFS. $\mathbf{G}$, Visualization of one $C B_{1} R+$ basket cell by digital rendering of fluorescent images (two superimposed 70 - $\mu$ m-thick sections). Scale

perisomatic-targeting interneurons is shown in Figure $1 C$. The remaining six perisomatic-targeting cells that did not show LTP were negative for parvalbumin and positive for $\mathrm{CB}_{1} \mathrm{R}$ (Fig. $1 F, G$ ) (supplemental Table 2, available at www. jneurosci.org as supplemental material). We conclude that perisomatic-targeting interneurons positive for either PV or $\mathrm{CB}_{1} \mathrm{R}$ show strict cell type-specific plasticity in the CA1 area. LTP was induced in seven of eight identified $\mathrm{PV}+$ perisomatictargeting interneurons but not in any of the identified $\mathrm{CB}_{1} \mathrm{R}+$ basket cells (Fig. $1 \mathrm{H}$ ).

\section{LTP or LTD occurs in interneurons} with distinct axonal target domains In contrast to the perisomatic-targeting interneurons, dendrite-targeting $\mathrm{PV}+$ or $\mathrm{CB}_{1} \mathrm{R}+$ interneurons did not show LTP at all. Seven cells tested with HFS were identified as bistratified cells. This cell type is immunopositive for PV, somatostatin, and NPY, and their axons innervate mainly pyramidal cell dendrites in str. radiatum and oriens (Halasy et al., 1996; Pawelzik et al., 2002; Klausberger et al., 2004). Remarkably, in five of seven bistratified cells, HFS induced LTD (reduction of the EPSP initial slope to at least $75 \%$ of baseline), whereas two cells showed no significant change in EPSP slope (Fig. $2 A, B)$. LTD $(63 \pm 3 \%, p<$ $0.005, n=5$ ) in the bistratified cells was restricted to the stimulated pathway (control pathway, $105 \pm 3 \%$ ). The systematic difference in plasticity between perisomatic- and dendrite-targeting $\mathrm{PV}+$ cells reported here is unlikely to be explained by different postsynaptic membrane potential or action potential firing in these cells during afferent stimulation, because these measures were similar in the cell types (supplemental Fig. 1, available at www.jneurosci.org as supplemental material). Five interneurons, also studied with HFS, with axons mainly in the dendritic layers, were immunopositive for $\mathrm{CB}_{1} \mathrm{R}$ and negative for PV (Ali, 2007) (supplemental Table 2, available at www. jneurosci.org as supplemental material). None of these $\mathrm{CB}_{1} \mathrm{R}+$ non-basket cells

bar, $100 \mu \mathrm{m}$. Bottom, Immunofluorescence micrographs of a biocytin-labeled (green) axon segment $\left(C_{1} R\right.$, yellow, laser confocal image). Scale bar, $10 \mu \mathrm{m}$. H, Comparison of baselinenormalized average EPSPs in all perisomatic-targeting cells 15-20 min after HFS relative to control pathways. Filled symbols indicate tetanized pathway, and open symbols show the control pathway. LTP is consistent in the PV+ interneuron types. Significance levels indicate a difference between pathways $\left({ }^{* *} p<0.01,{ }^{* * *} p<0.005\right.$, unpaired $t$ test $)$. 

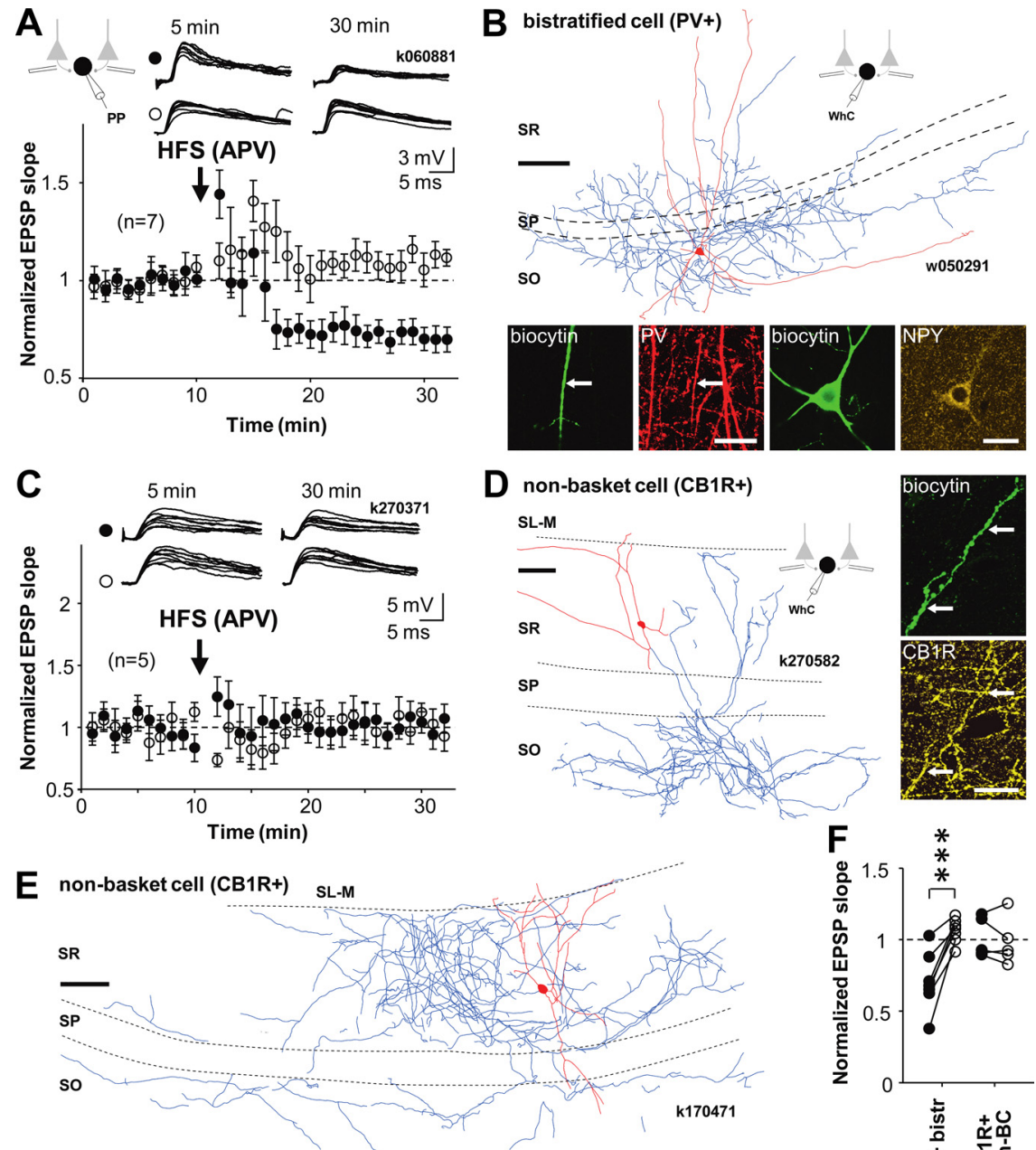

Figure 2. LTP is specific to perisomatic-targeting PV + cell types. EPSPs in PV+ bistratified cells that target to the dendritic domain of CA1 pyramidal cells show LTD. EPSPs in interneurons that express $C_{1} R$ and innervate pyramidal cell dendrites show no lasting plasticity. Perforated patch (PP) recordings. A, Mean \pm SE of EPSP slope in seven identified bistratified cells. HFS to one of the pathways (filled symbols) induced pathway-specific LTD. Open symbols show EPSP in the untetanized control pathway. Top, Consecutive EPSP traces during baseline and $20 \mathrm{~min}$ after the HFS in the two pathways. Schematic shows experimental design. $\boldsymbol{B}$, Visualization of one bistratified cell by digital rendering of fluorescent images (dendrites in red and axon in blue, from one $70 \mu \mathrm{m}$ section) recorded in whole cell (WhC). Scale bar, $100 \mu \mathrm{m}$. Fluorescence micrographs demonstrating immunopositivity for PV (red, laser confocal images) as tested in a dendrite (indicated by arrow) and for neuropeptide $Y$ (yellow, structured illumination microscope images) in the soma. Biocytin is shown in green. Scale bar, $20 \mu \mathrm{m}$. C, Mean \pm SE of EPSP slope from five cells identified as dendrite-targeting CA1 interneurons expressing $\mathrm{CB}_{1}$ R. None of the cells showed significant lasting plasticity in the EPSP. Top, Consecutive EPSPs in the two pathways during baseline and $20 \mathrm{~min}$ after HFS. D, Visualization of a $\mathrm{CB}_{1} \mathrm{R}+$ non-basket cell (k270582, reconstruction from two $70-\mu \mathrm{m}$ thick sections), recorded in perforated and whole-cell mode. Axon ramifies in strata oriens and radiatum but not in pyramidale. It was verified that the main axon originated $55 \mu \mathrm{m}$ away from the soma at a point at which the dendrite turned by $90^{\circ}$ degrees. Scale bar, $100 \mu \mathrm{m}$. Fluorescence micrographs demonstrating immunopositivity for $C_{1} R$ in an axon visualized with biocytin (green, indicated by arrow; structured illumination microscopic images). Scale bar, $20 \mu \mathrm{m}$. $\boldsymbol{E}$, Another example of a non-basket cell (k170471, dendrites in red, from three $70-\mu \mathrm{m}$-thick sections, axon in blue, from two sections) recorded in whole-cell mode that was also confirmed to be positive for $C_{1} R$ (data not shown) (but see supplemental Table 2, available at www.jneurosci.org as supplemental material). Note the rich axon arborization in strata radiatum and oriens but the clear absence of axon concentration in str. pyramidale. Scale bar, $100 \mu \mathrm{m}$. $\boldsymbol{F}$, Comparison of baseline-normalized EPSP slopes after HFS (20 min) in the two types of dendrite-targeting interneurons. Filled and open symbols indicate tetanized and control pathways, respectively $\left({ }^{* *} p<0.005\right.$, unpaired $t$ test). SL-M, str. lacunosum moleculare; SR, str. radiatum; SP, str. pyramidale; SO, str. oriens.

showed a significant change in EPSP slope 15 min after the HFS, indicating an absence of LTP or LTD (Fig. 2C-E). Thus, LTD occurred specifically in dendrite-innervating $\mathrm{PV}+$ bistratified cells under this induction protocol (Fig. $2 F$ ).

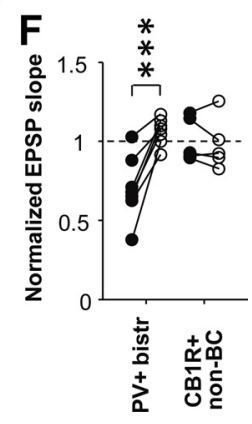

$\mathrm{CB}_{1} \mathrm{R}+$ interneuron types with intact NMDAR-mediated transmission do not show LTP or LTD

Although $\mathrm{CB}_{1} \mathrm{R}+$ basket cells did not demonstrate NMDAR-independent LTP, we asked whether they might show NMDARdependent LTP similar to pyramidal cells and some GABAergic interneurons in other hippocampal circuits (Kullmann and Lamsa, 2007). We performed experiments in four post hoc identified $\mathrm{CB}_{1} \mathrm{R}+$ basket cells in the absence of NMDAR blockers and depolarized the postsynaptic cell to $0 \mathrm{mV}$ in current clamp during HFS. This was associated with intense firing of the postsynaptic cell $(63.3 \pm 3.7$ action potentials evoked by a 100-pulse train, $n=8$ in 4 cells). This protocol, however, also failed to induce a lasting ( $\geq 15 \mathrm{~min}$ ) change in the EPSPs (Fig. $3 A, B$ ).

Next, we asked whether $\mathrm{CB}_{1} \mathrm{R}+$ cells would show plasticity with a different stimulation protocol. In 10 additional identified $\mathrm{CB}_{1} \mathrm{R}+$ cells, we used theta-burst stimulation (TBS) while the postsynaptic cell was in current clamp at resting membrane potential. After baseline, highfrequency stimulation trains $(100 \mathrm{~Hz}$, five pulses) were delivered to one pathway at theta frequency $(5 \mathrm{~Hz}$, four cycles), whereas the second pathway served as control. The protocol was applied five times with $20 \mathrm{~s}$ interval (100 stimulation pulses altogether) (Fig. 3C). The afferent stimulation induced depolarization above firing threshold in the cells (34.0 \pm 8.8 postsynaptic action potentials by 100 stimulation pulses). Both pathways were followed at least $15 \mathrm{~min}$ after TBS. Four cells were identified as $\mathrm{CB}_{1} \mathrm{R}+$ basket cells (Fig. $3 D$ ) and six cells as $\mathrm{CB}_{1} \mathrm{R}+$ nonbasket cells (Fig. 3E). Neither of these cell populations showed significant potentiation or depression (paired $t$ test) or difference between the pathways $15 \mathrm{~min}$ after the TBS (unpaired $t$ test). Averages of baselinenormalized EPSPs are shown in Figure 3F.

\section{Plasticity occurs in interneurons with CP-AMPARs}

We next asked whether this cell typespecific plasticity we observed was correlated with the presence of CP-AMPARs in these cells (Lei and McBain, 2004; Isaac et al., 2007; Lamsa et al., 2007). We recorded EPSCs in whole-cell mode from the repatched cells (when access resistance allowed voltage clamp; see Materials and Methods). In addition, we recorded from a separate set of interneurons in wholecell only and subsequently identified their cell type (supplemental Tables 1, 2, available at www.jneurosci.org as supplemental material). Stimulation from str. oriens/alveus in all PV + cells, including both control and tetanized pathways in repatched cells, 

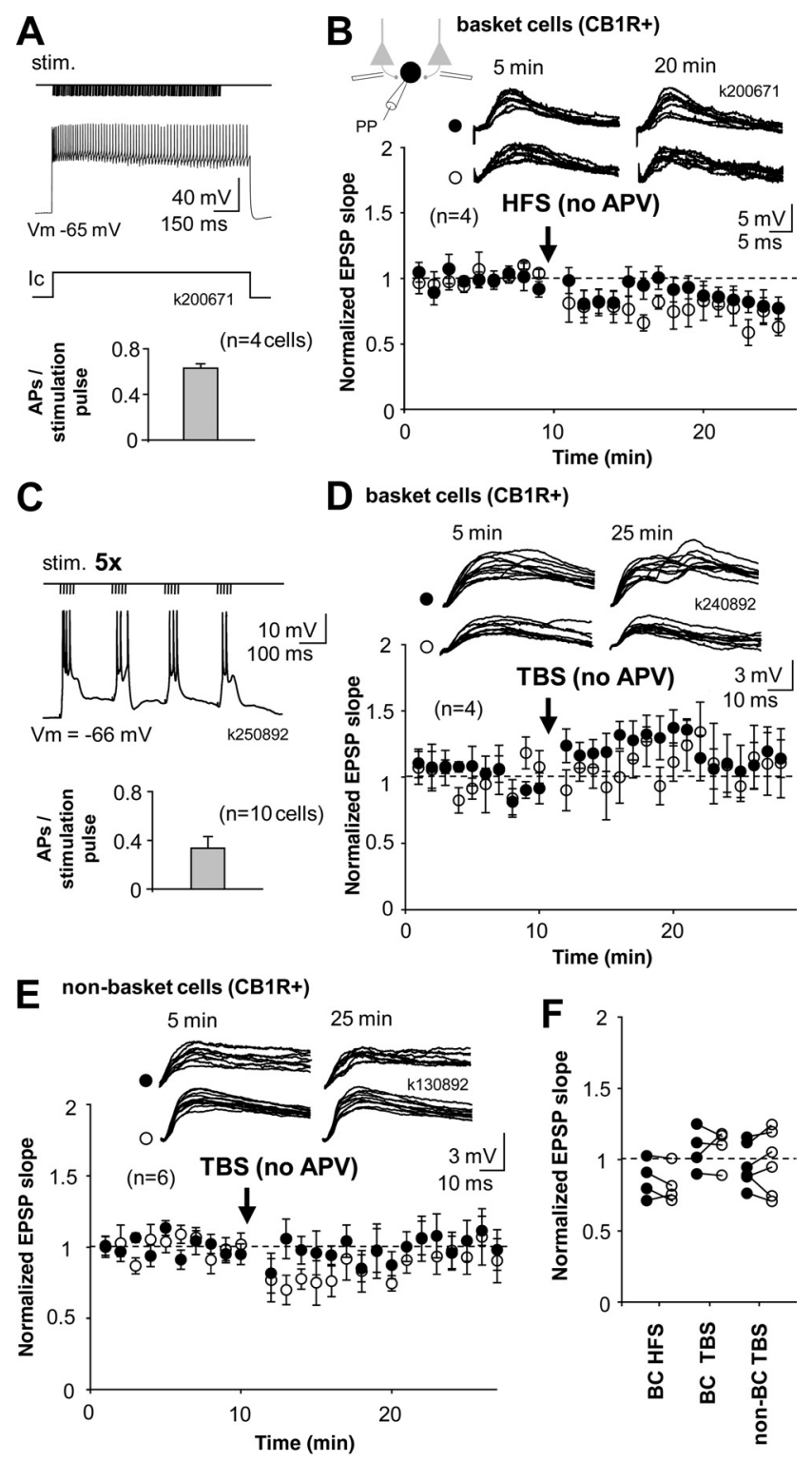

Figure 3. $\quad\left(B_{1} R+\right.$ basket cells and non-basket cells with intact NMDAR-mediated transmission fail to show long-term plasticity. $A$, Schematic shows HFS protocol; tetanic stimulation (stim.) to one pathway is paired with depolarization of postsynaptic cell to $0 \mathrm{mV}$ in current clamp (Ic). NMDARs are not blocked. Histogram shows that intense firing of postsynaptic action potentials (APs) was associated with presynaptic stimuli. $\boldsymbol{B}$, Mean \pm SE of EPSP slope from four cells recorded in perforated patch and identified post hoc as $C B_{1} R+$ basket cells. None of the cells showed significant lasting plasticity in the EPSP. Top, EPSPs in the two pathways during baseline and 10 min after HFS. C, Schematic shows TBS stimulation protocol; trains of stimuli ( $100 \mathrm{~Hz}$, five pulses) are delivered to one pathway at $5 \mathrm{~Hz}$, while postsynaptic cell is at resting membrane potential (action potentials truncated). Histogram shows number of postsynaptic action potentials elicited by presynaptic stimuli. $\boldsymbol{D}$, Perforated patch recording from four $\mathrm{CB}_{1} \mathrm{R}+$ basket cells showed EPSPs without lasting plasticity. EPSP slope in theta-bursted pathway was not different from baseline or from control pathway $15 \mathrm{~min}$ after the TBS. Top, Consecutive EPSP traces from one experiment. $\boldsymbol{E}$, Similar recordings show lack of long-term plasticity of EPSPs in $\mathrm{CB}_{1} \mathrm{R}+$ non-basket cells $(n=6)$. Cells were repatched and identified as above. Top, EPSPs from an individual experiment. $\boldsymbol{F}$, Baseline-normalized average EPSPs in the three types of experiments shown above. Filled symbols indicate HFS- or TBS-treated pathway, and open symbols show the control pathway. Data are taken 10-15 min after the HFS or TBS.

elicited strongly inward rectifying EPSCs (Fig. 4A), indicating a high percentage of CP-AMPARs in these synapses under baseline conditions as well as after plasticity (Jonas et al., 1994; Geiger et al., 1995; Lei and McBain, 2004; Lamsa et al., 2007). The RI (see
Materials and Methods) of EPSCs was consistently low in PV+ cell types (Catania et al., 1998). RI in axo-axonic cells was $0.09 \pm$ $0.02(n=13$ stimulation pathways tested in 8 cells $)$, in basket cells was $0.12 \pm 0.03$ ( $n=10$ in 6 cells), and in bistratified cells was $0.11 \pm 0.02(n=22$ in 12 cells $)$. Although in most PV + cells two stimulation pathways from str. oriens/alveus were tested, in some cells, the control pathway was stimulated in str. radiatum. EPSCs evoked from str. radiatum showed similar strong inward rectification (RI of $0.07 \pm 0.05, n=6$ pathways). In contrast, RI in $\mathrm{CB}_{1} \mathrm{R}+$ basket cells ( $n=16$ in 14 cells) and non-basket cells $(n=$ 14 in 10 cells) was $0.72 \pm 0.03(n=30)$, reminiscent of that recorded in pyramidal cells (supplemental Fig. 2, available at www.jneurosci.org as supplemental material). In only 5 of the 30 pathways recorded in $\mathrm{CB}_{1} \mathrm{R}+$ cells was rectification prominent $(\mathrm{RI}<0.5)$ (Fig. 4B). In some recordings, another stimulation was delivered from str. radiatum, which evoked EPSCs with RI of $0.67 \pm 0.07$ ( $n=7$ pathways).

We next tested the effect of blocking CP-AMPARs on synaptic excitation of these interneuron types. EPSCs recorded in identified interneurons in whole-cell mode were evoked by stimulation in str. oriens/alveus, and they were strongly suppressed after wash-in of the CP-AMPAR blocker PhTx $(10 \mu \mathrm{M})$ in all PV+ interneuron types (Fig. 4C,D). EPSC amplitude was reduced to $44 \pm 6 \%(p<0.005$, paired $t$ test $)$ by $\operatorname{PhTx}(n=9$, includes 3 axo-axonic, 3 basket cells, and 3 bistratified cells). In contrast, PhTx had a small effect on EPSCs in $\mathrm{CB}_{1} \mathrm{R}+$ basket cells (in PhTx: $86 \pm 9 \%, n=11$ cells, $p<0.05)$. As a reference, we confirmed that $\mathrm{PhTx}$ had no effect on synaptic excitation of identified CA1 pyramidal cells with a linear EPSC $I-V$ relation (supplemental Fig. 2, available at www.jneurosci.org as supplemental material). Thus, CP-AMPAR blockade inhibits excitation of PV + interneurons to a much stronger degree than of $\mathrm{CB}_{1} \mathrm{R}+$ interneurons.

Disynaptic GABAergic transmission in CA1 pyramidal cells is strongly suppressed by CP-AMPAR blockers

Based on the strong effect of CP-AMPAR blockade on the excitation of PV+ interneurons, we tested the effect of PhTx on disynaptic inhibition in CA1 pyramidal cells. We recorded from the soma in whole-cell mode and stimulated in str. oriens/alveus far $(\geq 1 \mathrm{~mm})$ from the recording site and close to the subiculum. $\mathrm{GABA}_{\mathrm{B}}$ and glutamate NMDA receptors were blocked with CGP55845 (1 $\mu \mathrm{M})$ and DL-APV $(100 \mu \mathrm{M})$, respectively. Cells were voltage clamped to the reversal of glutamatergic EPSCs ( 0 to +10 $\mathrm{mV}$ ). We first measured maximum disynaptic IPSC (the disynaptic nature was verified at the end by applying NBQX at $10 \mu \mathrm{M}$ ) for stimulation pathways. Next, stimuli with reducing intensities were applied to dissect the contribution of interneurons with CP-AMPARs at various stimulation strengths (see Materials and Methods). IPSCs were recorded in control conditions and after wash-in of PhTx $(10 \mu \mathrm{M})$. PhTx significantly reduced the amplitude of disynaptic IPSCs at each stimulation strength, but the inhibitory effect of $\mathrm{PhTx}$ was most pronounced in low-amplitude IPSCs (Fig. $5 A$ ). When $\sim 30 \%$ of the maximum IPSC was used, PhTx suppressed the disynaptic IPSC to $26 \pm 3 \%$ of $\operatorname{control}(n=$ 5 slices, $p<0.005$ ) (Fig. 5B), indicating a strong contribution of interneurons with CP-AMPARs to the IPSC (Jonas et al., 2004). In comparison, when the $100 \%$ IPSC was tested, $\mathrm{PhTx}$ reduced the disynaptic IPSC to $74 \pm 4 \%(p<0.01)$. We confirmed that PhTx had no direct effect on GABAergic IPSCs (supplemental Fig. 3, available at www.jneurosci.org as supplemental material). 

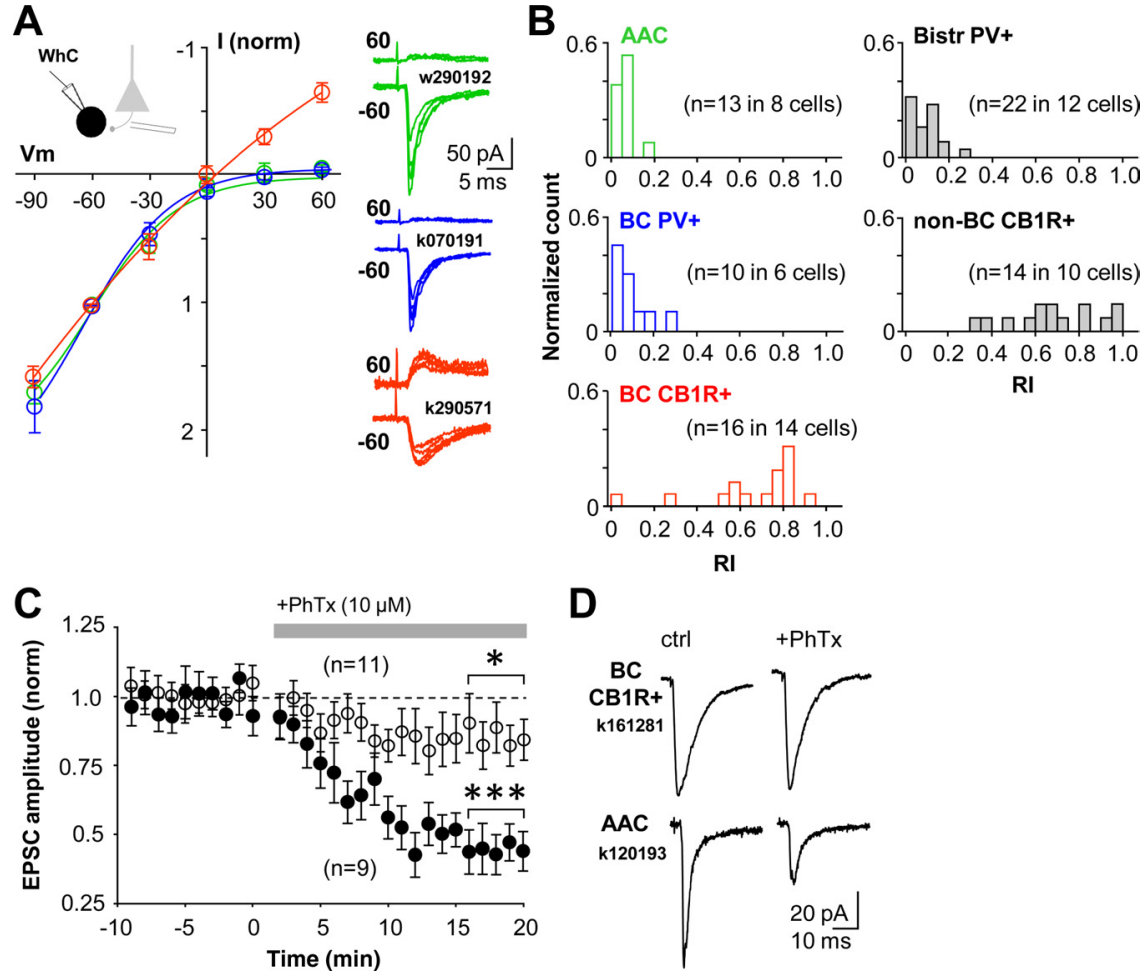

D

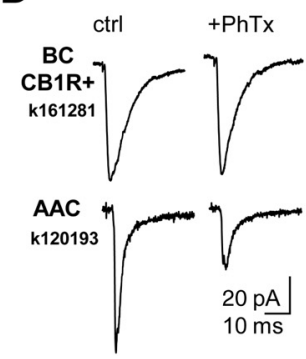

Figure 4. $\quad P V+$ interneurons are excited via CP-AMPARs and $C_{1} R$-expressing interneurons via calcium-impermeable AMPARs in the CA1 area. $A, I-V$ relations of AMPAR-mediated EPSCs are interneuron type specific. PV + basket cells and axo-axonic cells have highly inward rectifying EPSCs, which is a hallmark of CP-AMPARs. In contrast, EPSCs in $\mathrm{B}_{1} R+$ basket cells show more linear current-voltage relation. EPSCs were evoked by stimulation in str. oriens/alveus. Mean \pm SE of normalized $/-V$ relationship in the three perisomatic-targeting cell types illustrated in colors (green for axo-axonic, blue for PV + basket cells, and red for $\mathrm{CB}_{1} \mathrm{R}+$ basket cells). Right, EPSCs at +60 and $-60 \mathrm{mV}$ in three different cells (color coding indicates cell type as above). WhC, Whole-cell mode. $B$, Histograms showing EPSC Rls in the five different interneuron types. Rls in PV + interneuron types (AAC, PV+ BC, Bistr $P V+$ ) are on average 0.11 , whereas in $C B_{1} R$-expressing interneurons $\left(B C C_{1} R+\right.$ and non- $B C\left(B_{1} R+\right)$ Rls are on average 0.75 . Color coding of perisomatic-targeting interneuron types is as in $A$. C, (P-AMPAR blocker PhTx blocks excitatory input to PV+ interneuron types (filled symbols) but has a small effect on EPSCs in $C_{1} R+$ cells $(n=11, p>0.05$; open symbols). Data show mean $\pm \mathrm{SE}$, and a horizontal bar indicates timing of PhTx wash-in. PV + cells include three basket, three axo-axonic, and three bistratified cells. $\left(B_{1} R+\right.$ cells are basket cells. Significance level indicates difference from baseline $\left({ }^{* * *} p<0.005\right.$, paired $t$ test). $D$, Averaged EPSCs in one $\mathrm{CB}_{1} \mathrm{R}$-expressing basket cell and in an axo-axonic cell during baseline and after wash-in of $\mathrm{PhTx}$ ( $20 \mathrm{~min}$ ).

\section{Long-term potentiation of disynaptic GABAergic transmission involves interneurons with CP-AMPARs}

Finally, we asked whether plasticity in the inputs to interneurons with CP-AMPARs could change disynaptic inhibition projected onto CA1 pyramidal cells. Given that LTP or LTD in interneurons with CP-AMPARs is induced without strong postsynaptic depolarization and that repetitive afferent stimulation induces robust plasticity in synapses recruiting these cells, we hypothesized that the same afferent stimulation might be able to potentiate or depress disynaptic GABAergic transmission. We recorded IPSCs in whole-cell mode from CA1 pyramidal cell soma clamped to the reversal of glutamatergic EPSCs as above and stimulated at two different locations in str. oriens/alveus. One electrode was positioned as above close to subiculum and another electrode close to the CA2 area. $\mathrm{GABA}_{\mathrm{B}}$ and glutamate NMDARs were blocked. Given that endocannabinoid receptor activation can mediate depression in certain GABAergic synapses onto pyramidal cells (Földy et al., 2007; Heifets et al., 2008) and because this depression may also be induced by high-frequency electrical stimulation (Chevaleyre and Castillo, 2003; Lamsa et al., 2005), $\mathrm{CB}_{1}$ Rs were blocked with AM-251 (5-10 $\left.\mu \mathrm{M}\right)$. Stimulation intensity was set to $\sim 30 \%$ of the maximum disynaptic IPSC amplitude in the pathways as above to maximize relative contribution of CP-AMPAR-containing interneurons in disynaptic IPSC (supplemental Fig. 4, available at www.jneurosci. org as supplemental material). After a baseline, the disynaptic pathway from the subicular site was stimulated with HFS, whereas the untetanized pathway was used as control (Fig. 6A). Significant LTP (potentiation of averaged IPSC amplitude to at least $125 \%$ of baseline) was generated in five of eight slices, although potentiation varied in amplitude. Baselinenormalized average of IPSC amplitudes in all eight slices showed potentiation in the tetanized pathway to $139 \pm 8 \%(p<$ $0.005,25 \mathrm{~min}$ after the HFS), whereas the average of the control pathway did not change $(89 \pm 7 \%$ ) (Fig. $6 B$ ). Pathway specificity of LTP was tested with unpaired $t$ test $(p<0.005)$ (Fig. $6 C)$. Again, the disynaptic nature of IPSCs was verified by blockade of the IPSC with NBQX $(10 \mu \mathrm{M})$ at the end of each experiment.

We repeated the same experiment in the presence of PhTx $(10 \mu \mathrm{M})$ to block excitation of interneurons with CP-AMPARs. IPSC intensity was set up similarly to 30\% in the pathways (supplemental Fig. 4, available at www.jneurosci.org as supplemental material), and HFS was delivered to the disynaptic pathway from the subicular site (Fig. 6D). Interestingly, HFS did not elicit lasting potentiation in any of the eight slices studied (Fig. 6E). Twenty minutes after the tetanus, IPSC amplitudes were $82 \pm 5 \%$ in the tetanized pathway and $88 \pm 7 \%$ in the untetanized control pathways (Fig. $6 F$ ). Although this moderate suppression of IPSC was significant $(p<$ 0.05 ) compared with baseline, it was not pathway specific. We confirmed that HFS does not change the amplitude of monosynaptic GABAergic IPSCs by reproducing the experiment above but in the continuous presence of NBQX $(10 \mu \mathrm{M})$ and stimulating closer to the recording site in str. oriens (Fig. 6G). Together, the results demonstrate that LTP of disynaptic GABAergic transmission recorded in CA1 pyramidal cell somata involves interneurons with CP-AMPARs.

\section{Discussion}

Here we have shown that excitatory connections to hippocampal interneurons express long-term plasticity in a cell typedependent manner (Kullmann and Lamsa, 2007; Klausberger and Somogyi, 2008). Lasting plasticity in the GABAergic interneurons correlates with the expression of certain neurochemical markers and the axonal target domain of the interneurons. These results highlight the importance of carefully identifying interneurons in long-term plasticity studies. The two forms of plasticity are likely to modulate the synaptic strength from pyramidal cells to local GABAergic interneurons. Localization of LTP and LTD at separate and defined GABAergic microcircuits emphasizes the specified roles of distinct interneuron types in hippocampal function (Santhakumar and Soltesz, 2004; Freund and Katona, 2007; Klausberger and Somogyi, 2008). 
Our results demonstrate that activityinduced plasticity takes place at excitatory synapses onto hippocampal PV + interneurons, whereas afferents onto $\mathrm{CB}_{1} \mathrm{R}+$ cells do not show plasticity. Although $\mathrm{PV}+$ and $\mathrm{CB}_{1} \mathrm{R}+$ interneurons provide parallel sources for perisomatic and dendritic innervation of pyramidal cells, $\mathrm{PV}+$ neurons presumably play a major role in the synchronization of neuronal groups that process, transfer, and store information during network oscillations (Buzsáki and Draguhn, 2004; Bartos et al., 2007; Fuchs et al., 2007; Mann and Paulsen, 2007; Tukker et al., 2007; Klausberger and Somogyi, 2008; Cardin et al., 2009; Sohal et al., 2009). $\mathrm{CB}_{1} \mathrm{R}+$ interneurons may be less critical for synchronizing pyramidal cells, and they may modulate ensemble activities as a function of subcortical inputs (Freund and Katona, 2007). Activity-induced synaptic plasticity and modulatory fine-tuning plasticity appear to be located in separate and complementary GABAergic microcircuits provided by $\mathrm{PV}+$ and $\mathrm{CB}_{1} \mathrm{R}+$ cells, respectively (Freund and Katona, 2007). However, we cannot fully exclude a possibility that synapses onto $\mathrm{CB}_{1} \mathrm{R}+$ cells could undergo long-term plasticity under certain conditions. For example, permissive signal from an extrahippocampal locus might be needed to allow plasticity in these cells (Isaac et al., 2009; Varga et al., 2009). In addition, afferent pathways emerging from a distinct population of glutamatergic hippocampal cells may behave differently. This, however, would not change the fact that, in general, the plasticity rules are very different in $\mathrm{PV}+$ and $\mathrm{CB}_{1} \mathrm{R}+$ cells.

$\mathrm{PV}+$ cells show plasticity that is specific to the efferent target domain, such that perisomatic-targeting GABAergic circuits are potentiated and dendritic-targeting neurons are depressed. LTP increases the excitatory drive onto perisomatic-targeting inhibitory interneurons in a synapse-specific manner. The potentiated excitatory afferent synapse at the GABAergic cell has an increased contribution to its firing and consequently to the synchronization of its target cell assembly during network oscillation. In addition, depressed recruitment of dendritic-targeting bistratified cells would promote temporal integration of excitatory input to pyramidal cells from the CA3 area (Cossart et al., 2001). This in turn might increase the ability of CA1 cells to resonate with CA3 pyramidal cells and could lower the threshold for LTP in CA3-CA1 synapses (Gustafsson et al., 1987), supporting rearrangement of temporal relationships within affected CA1 populations (Dragoi et al., 2003). However, because the inputs to different PV + cell types likely arrive at distinct phases of oscillations in vivo (Klausberger and Somogyi, 2008), each interneuron type would possibly experience optimal plasticity-inducing conditions at different times (Kullmann and Lamsa, 2007).

Information processing requires the interactions within or between cell assemblies to be flexible, but the inputs to PV + cells have long been considered poorly modifiable. Synchronized cell assembly formation during oscillations is dynamic and applies to particular representations and contexts. It is therefore expected
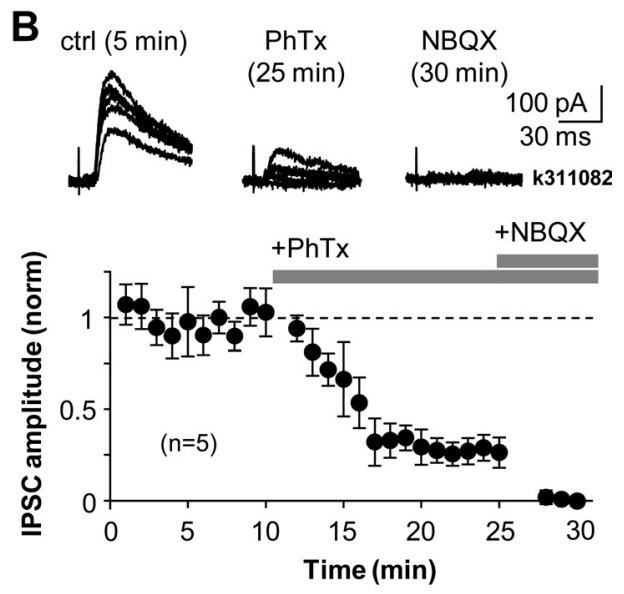

$(n=5)$

$\square$ ctrl

$\square+\mathrm{PhTx}$

+ NBQX

Figure 5. Disynaptic GABAergic transmission in the CA1 involves activation of interneurons with CP-AMPARs. CP-AMPAR (me maximum (maximum, 75\%, and 30\% amplitudes) and was most pronounced at lowe

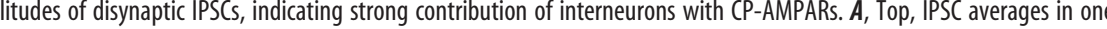
$30 \%$ of maximum IPSC was used throughout experiment. Horizontal bars indicate timing of drug application as indicated. Top, Consecutive IPSCs in one experiment during baseline and after exposure to the drugs.

that the synaptic strengths between pyramidal cells and interneurons also change in behaviorally relevant timescales (Csicsvari et al., 1998). The cell type-specific plasticity that we demonstrate here and, in particular, the contrasting effect of the same induction pattern leading to LTP or LTD in perisomatic- or dendritetargeting PV + cells, respectively, is a good candidate mechanism for maintaining the necessary flexibility in connection strengths during the formation or dissolution of cell assemblies.

What might be potential cellular mechanisms for LTP and LTD in PV + cells? Plasticity was independent of NMDARs and occurred at synapses with CP-AMPARs. Long-term plasticity in many interneurons depends on CP-AMPARs (Mahanty and Sah, 1998; Laezza et al., 1999; Kullmann and Lamsa, 2007; Lamsa et al., 2007; Oren et al., 2009). Both LTP and LTD in PV+ interneuron types were induced at membrane potentials below somatic firing threshold, consistent with previous reports on CP-AMPARmediated LTP and LTD (Laezza et al., 1999; Lamsa et al., 2007) and AMPAR subunit expression patterns in interneurons (Jonas et al., 1994; Geiger et al., 1995; Catania et al., 1998). In line with this, potentiation of disynaptic GABAergic transmission recorded in pyramidal cells required interneurons with CPAMPARs, although this does not necessarily indicate an inductive role for these receptors in the LTP (Asrar et al., 2009). However, CP-AMPARs would provide temporally and spatially highly restricted calcium influx in aspiny postsynaptic interneuron dendrites (Goldberg and Yuste, 2005). Contributions of CPAMPARs and other mechanisms including metabotropic glutamate receptors and voltage-gated calcium channels to LTP and LTD (Laezza et al., 1999; Alle et al., 2001; Perez et al., 2001; Lei and McBain, 2004; Lamsa et al., 2007; Galván et al., 2008; Sarihi et al., 2008) remain to be dissected in PV+ interneurons. Properties may vary between distinct afferent pathways to the same cell (Tóth and McBain, 1998). Most glutamatergic inputs to 

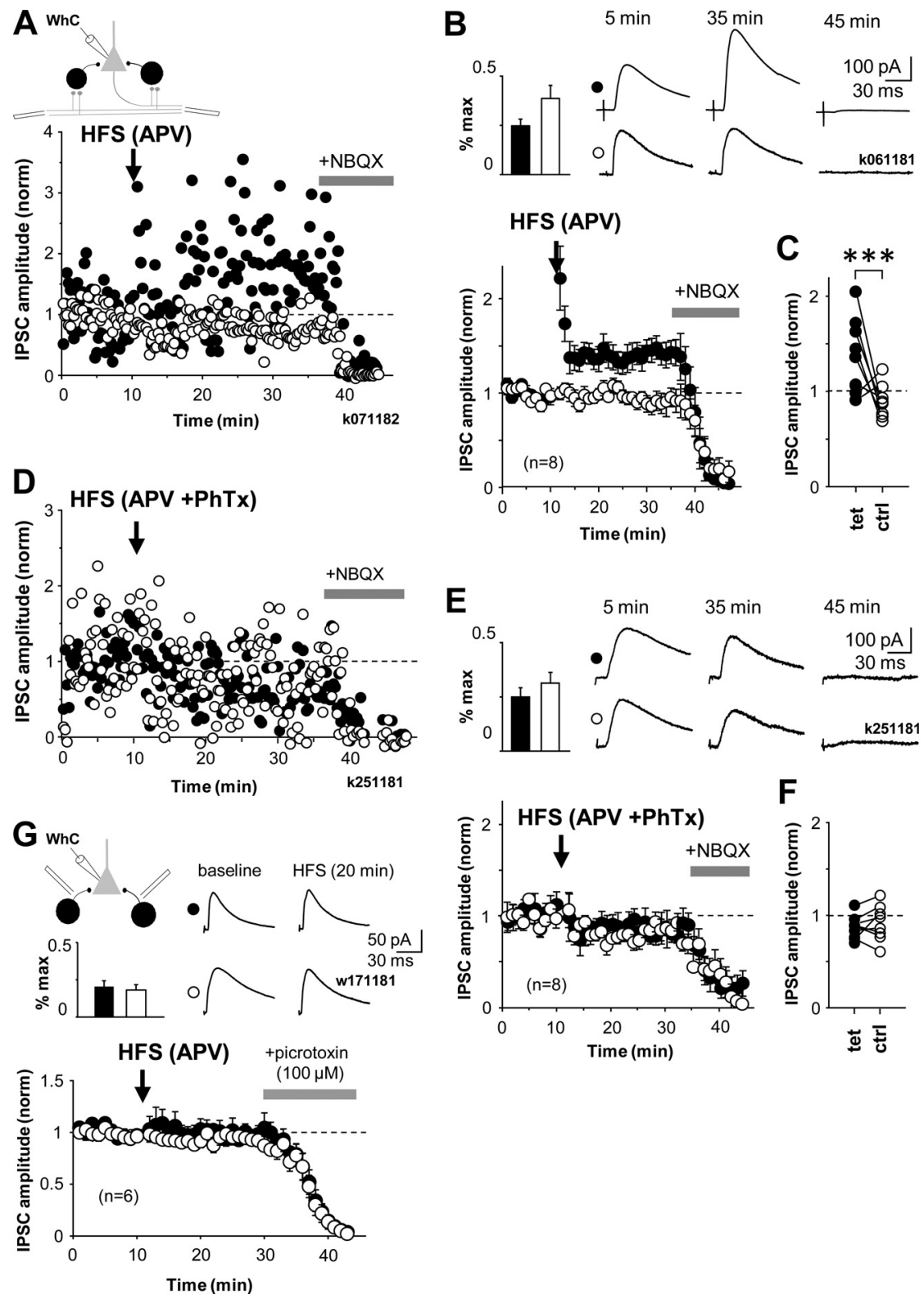

Figure 6. LTP of disynaptic GABAergic transmission in str. oriens is NMDAR independent, pathway specific, and requires interneurons with CP-AMPARs. A, HFS induces long-term potentiation in disynaptic IPSCs recorded in CA1 pyramidal cell somata. Two disynaptic pathways were stimulated with electrodes positioned in str. oriens/alveus. Schematic shows experimental design. IPSC amplitude was adjusted to 30\% of maximum. After a baseline, HFS was given to one of the two pathways (filled symbols), the other pathway was not tetanized and was used as a control (open symbols). LTP was observed for $25 \mathrm{~min}$. Full blockade of IPSCs at the end by NBQX (wash-in indicated by horizontal bar) confirmed the disynaptic nature of the IPSCs. Data are from one cell, in the presence of DL-APV (100 $\mu \mathrm{M})$ and CGP55845 ( $1 \mu \mathrm{m})$. In addition, cannabinoid receptors were blocked with AM-251 (10 $\mu \mathrm{M})$. WhC, Whole-cell mode. $\boldsymbol{B}$, Similar recordings as in $\boldsymbol{A}$, averaged from eight cells showing mean \pm SE of disynaptic IPSC amplitude. Top left, Bar histogram shows disynaptic IPSC strength relative to maximum in the pathways during baseline (mean $\pm \mathrm{SE}$ ). Top right, Averaged IPSCs at different time points in one cell as indicated. C, Comparison of averages of baseline-normalized IPSC amplitudes in all experiments 20 min after the HFS. Filled and open symbols indicate tetanized and control pathways as above ( ${ }^{* *} p<0.005$, unpaired $t$ test). D, LTP of disynaptic GABAergic transmission fails in the presence of the (P-AMPAR blocker PhTx. Similar experiment as in $\boldsymbol{A}$ but in the presence of $\mathrm{PhTx}(10 \mu \mathrm{M})$. $\boldsymbol{E}$, Disynaptic IPSC mean \pm SE eight experiments in the presence of PhTx as in $\boldsymbol{D}$. Insets as in $\boldsymbol{B}$. $\boldsymbol{F}$, Averages of baseline-normalized IPSCs in all experiments 20 min after the HFS. $\mathbf{G}$, HFS does not change monosynaptic GABAergic IPSC. Monosynaptic IPSCS measured in CA1 pyramidal cell soma elicited by stimulation from str. oriens. IPSC amplitudes were adjusted on average below $30 \%$ of maximum (inset bar histogram). HFS was applied to one pathway (filled symbols) after a baseline period. Control pathway is shown by open symbols. HFS failed to induce lasting changes in the monosynaptic IPSC. Plot shows mean \pm SE of baseline-normalized IPSC amplitude in six cells. IPSCs were blocked by picrotoxin at the end. $\mathrm{GABA}_{\mathrm{B}}$, ionotropic glutamate, and $\mathrm{CB}_{1}$ Rs were blocked with (GP55845 (1 $\left.\mu \mathrm{M}\right), \mathrm{NBQX}(10 \mu \mathrm{M}), \mathrm{DL}-\mathrm{APV}$ $(100 \mu \mathrm{M})$, and AM-251 (10 $\mu \mathrm{M})$. Averaged IPSCS are shown from one experiment during baseline and after HFS (20 min). the three PV+ cell types reported here probably originate from CA1 and CA3 pyramidal cells, but the relative weight of these inputs is not known (Gulyás et al., 1999).

Synapses with CP-AMPARs provide the major pathway for long-term potentiation of disynaptic inhibition in the CA1 str. oriens/alveus, although potentiation level varied considerably between slices. This might be attributable to several factors. First, parallel depression of IPSCs in the dendritic domain of pyramidal cells might partially mask potentiation of IPSCs generated by perisomatic-targeting cells, although it is unclear whether LTD in bistratified cells results in reduced GABAergic transmission to pyramidal cell dendrites. However, because bistratified cells selectively target pyramidal cell dendrites, IPSCs from these interneuron types are much smaller at the level of the soma than IPSCs evoked by PV+ basket cells and axo-axonic cells (Maccaferri et al., 2000). In addition, number of bistratified cells is only one-quarter of all PV+ cells in the CA1 stratum pyramidale (Baude et al., 2007). This might explain why in most experiments IPSC potentiation was seen and why net depression of IPSC was not systematically observed. Second, stimulation of excitatory fibers in some cases may not have recruited PV+ perisomatic-targeting cells or the excitatory input failed to induce plasticity in these cells. If plasticity in PV + cells follows the anti-Hebbian rule, strong depolarization during afferent stimulation would compromise or prevent LTP in some cells (Kullmann and Lamsa, 2007; Lamsa et al., 2007). Although LTP in oriens-lacunosum moleculare interneurons (Perez et al., 2001; Lamsa et al., 2007), which also express PV at low level (Klausberger et al., 2003), may contribute to the potentiation of disynaptic IPSC, their selective innervation of pyramidal cell distal dendritic domains elicits strongly attenuated IPSCs at the level of pyramidal cell soma (Maccaferri et al., 2000).

In conclusion, our findings reveal remarkable cell type-specific plasticity rules in the highly diverse hippocampal GABAergic interneuron population. We suggest that cell type-dependent plasticity in interneurons may not be restricted to the hippocampal CA1 area. Similar rules might occur in other brain areas with region- and afferent-specific variability. Because the interneuron types studied in this work are found in most cortical areas, their plasticity may also have widespread contributions to cortical networks outside 
the hippocampus (Buzsáki and Draguhn, 2004; Santhakumar and Soltesz, 2004; Yazaki-Sugiyama et al., 2009).

\section{References}

Ali AB (2007) Presynaptic inhibition of GABAA receptor-mediated unitary IPSPs by cannabinoid receptors at synapses between CCK-positive interneurons in rat hippocampus. J Neurophysiol 98:861-869.

Alle H, Jonas P, Geiger JR (2001) PTP and LTP at a hippocampal mossy fiber-interneuron synapse. Proc Natl Acad Sci U S A 98:14708-14713.

Asrar S, Zhou Z, Ren W, Jia Z (2009) Ca permeable AMPA receptor induced long-term potentiation requires PI3/MAP kinases but not $\mathrm{Ca} / \mathrm{CaM}$ dependent kinase II. PLoS ONE 4:e4339.

Bartos M, Vida I, Jonas P (2007) Synaptic mechanisms of synchronized gamma oscillations in inhibitory interneuron networks. Nat Rev Neurosci 8:45-56.

Baude A, Bleasdale C, Dalezios Y, Somogyi P, Klausberger T (2007) Immunoreactivity for the GABAA receptor alphal subunit, somatostatin and Connexin36 distinguishes axoaxonic, basket, and bistratified interneurons of the rat hippocampus. Cereb Cortex 17:2094-2107.

Buzsáki G, Draguhn A (2004) Neuronal oscillations in cortical networks. Science 304:1926-1929.

Buzsáki G, Eidelberg E (1982) Direct afferent excitation and long-term potentiation of hippocampal interneurons. J Neurophysiol 48:597-607.

Cardin JA, Carlén M, Meletis K, Knoblich U, Zhang F, Deisseroth K, Tsai LH, Moore CI (2009) Driving fast-spiking cells induces gamma rhythm and controls sensory responses. Nature 459:663-667.

Carvalho TP, Buonomano DV (2009) Differential effects of excitatory and inhibitory plasticity on synaptically driven neuronal input-output functions. Neuron 61:774-785.

Catania MV, Bellomo M, Giuffrida R, Giuffrida R, Stella AM, Albanese V (1998) AMPA receptor subunits are differentially expressed in parvalbumin- and calretinin-positive neurons of the rat hippocampus. Eur J Neurosci 10: 3479-3490.

Chevaleyre V, Castillo PE (2003) Heterosynaptic LTD of hippocampal GABAergic synapses: a novel role of endocannabinoids in regulating excitability. Neuron 38:461-472.

Cossart R, Dinocourt C, Hirsch JC, Merchan-Perez A, De Felipe J, Ben-Ari Y, Esclapez M, Bernard C (2001) Dendritic but not somatic GABAergic inhibition is decreased in experimental epilepsy. Nat Neurosci 4:52-62.

Cowan AI, Stricker C, Reece LJ, Redman SJ (1998) Long-term plasticity at excitatory synapses on aspinous interneurons in area CA1 lacks synaptic specificity. J Neurophysiol 79:13-20.

Csicsvari J, Hirase H, Czurko A, Buzsáki G (1998) Reliability and state dependence of pyramidal cell-interneuron synapses in the hippocampus: an ensemble approach in the behaving rat. Neuron 21:179-189.

Dragoi G, Harris KD, Buzsáki G (2003) Place representation within hippocampal networks is modified by long-term potentiation. Neuron 39:843-853.

Földy C, Lee SY, Szabadics J, Neu A, Soltesz I (2007) Cell type-specific gating of perisomatic inhibition by cholecystokinin. Nat Neurosci 10:1128-1130.

Freund TF, Katona I (2007) Perisomatic inhibition. Neuron 56:33-42.

Fuchs EC, Zivkovic AR, Cunningham MO, Middleton S, Lebeau FE, Bannerman DM, Rozov A, Whittington MA, Traub RD, Rawlins JN, Monyer H (2007) Recruitment of parvalbumin-positive interneurons determines hippocampal function and associated behavior. Neuron 53:591-604.

Galván EJ, Calixto E, Barrionuevo G (2008) Bidirectional Hebbian plasticity at hippocampal mossy fiber synapses on CA3 interneurons. J Neurosci 28:14042-14055.

Geiger JR, Melcher T, Koh DS, Sakmann B, Seeburg PH, Jonas P, Monyer H (1995) Relative abundance of subunit mRNAs determines gating and $\mathrm{Ca}^{2+}$ permeability of AMPA receptors in principal neurons and interneurons in rat CNS. Neuron 15:193-204.

Goldberg JH, Yuste R (2005) Space matters: local and global dendritic $\mathrm{Ca}^{2+}$ compartmentalization in cortical interneurons. Trends Neurosci 28:158-167.

Gulyás AI, Megías M, Emri Z, Freund TF (1999) Total number and ratio of excitatory and inhibitory synapses converging onto single interneurons of different types in the CAl area of the rat hippocampus. J Neurosci 19:10082-10097.

Gustafsson B, Wigström H, Abraham WC, Huang YY (1987) Long-term potentiation in the hippocampus using depolarizing current pulses as the conditioning stimulus to single volley synaptic potentials. J Neurosci 7:774-780.

Halasy K, Buhl EH, Lörinczi Z, Tamás G, Somogyi P (1996) Synaptic target selectivity and input of GABAergic basket and bistratified interneurons in the CA1 area of the rat hippocampus. Hippocampus 6:306-329.

Heifets BD, Chevaleyre V, Castillo PE (2008) Interneuron activity controls endocannabinoid-mediated presynaptic plasticity through calcineurin. Proc Natl Acad Sci U S A 105:10250-10255.

Isaac JT, Ashby M, McBain CJ (2007) The role of the GluR2 subunit in AMPA receptor function and synaptic plasticity. Neuron 54:859-871.

Isaac JT, Buchanan KA, Muller RU, Mellor JR (2009) Hippocampal place cell firing patterns can induce long-term synaptic plasticity in vitro. J Neurosci 29:6840-6850.

Jonas P, Racca C, Sakmann B, Seeburg PH, Monyer H (1994) Differences in $\mathrm{Ca}^{2+}$ permeability of AMPA-type glutamate receptor channels in neocortical neurons caused by differential GluR-B subunit expression. Neuron 12:1281-1289.

Jonas P, Bischofberger J, Fricker D, Miles R (2004) Interneuron diversity series: fast in, fast out-temporal and spatial signal processing in hippocampal interneurons. Trends Neurosci 27:30-40.

Kairiss EW, Abraham WC, Bilkey DK, Goddard GV (1987) Field potential evidence for long-term potentiation of feed-forward inhibition in the rat dentate gyrus. Brain Res 401:87-94.

Klausberger T, Somogyi P (2008) Neuronal diversity and temporal dynamics: the unity of hippocampal circuit operations. Science 321:53-57.

Klausberger T, Magill PJ, Márton LF, Roberts JD, Cobden PM, Buzsáki G, Somogyi P (2003) Brain-state- and cell-type-specific firing of hippocampal interneurons in vivo. Nature 421:844-848.

Klausberger T, Márton LF, Baude A, Roberts JD, Magill PJ, Somogyi P (2004) Spike timing of dendrite-targeting bistratified cells during hippocampal network oscillations in vivo. Nat Neurosci 7:41-47.

Klausberger T, Marton LF, O’Neill J, Huck JH, Dalezios Y, Fuentealba P, Suen WY, Papp E, Kaneko T, Watanabe M, Csicsvari J, Somogyi P (2005) Complementary roles of cholecystokinin- and parvalbumin-expressing GABAergic neurons in hippocampal network oscillations. J Neurosci 25:9782-9793.

Kullmann DM, Lamsa KP (2007) Long-term synaptic plasticity in hippocampal interneurons. Nat Rev Neurosci 8:687-699.

Laezza F, Dingledine R (2004) Voltage-controlled plasticity at GluR2deficient synapses onto hippocampal interneurons. J Neurophysiol 92:3575-3581.

Laezza F, Doherty JJ, Dingledine R (1999) Long-term depression in hippocampal interneurons: joint requirement for pre- and postsynaptic events. Science 285:1411-1414.

Lamsa K, Heeroma JH, Kullmann DM (2005) Hebbian LTP in feed-forward inhibitory interneurons and the temporal fidelity of input discrimination. Nat Neurosci 8:916-924.

Lamsa KP, Heeroma JH, Somogyi P, Rusakov DA, Kullmann DM (2007) Anti-Hebbian long-term potentiation in the hippocampal feedback inhibitory circuit. Science 315:1262-1266.

Lapointe V, Morin F, Ratté S, Croce A, Conquet F, Lacaille JC (2004) Synapse-specific mGluR1-dependent long-term potentiation in interneurones regulates mouse hippocampal inhibition. J Physiol 555: 125-135.

Lei S, McBain CJ (2004) Two loci of expression for long-term depression at hippocampal mossy fiber-interneuron synapses. J Neurosci 24:2112-2121.

Losonczy A, Zhang L, Shigemoto R, Somogyi P, Nusser Z (2002) Cell type dependence and variability in the short-term plasticity of EPSCs in identified mouse hippocampal interneurones. J Physiol 542:193-210.

Maccaferri G, McBain CJ (1996) Long-term potentiation in distinct subtypes of hippocampal nonpyramidal neurons. J Neurosci 16:5334-5343.

Maccaferri G, Tóth K, McBain CJ (1998) Target-specific expression of presynaptic mossy fiber plasticity. Science 279:1368-1370.

Maccaferri G, Roberts JD, Szucs P, Cottingham CA, Somogyi P (2000) Cell surface domain specific postsynaptic currents evoked by identified GABAergic neurones in rat hippocampus in vitro. J Physiol 524:91-116.

Mahanty NK, Sah P (1998) Calcium-permeable AMPA receptors mediate long-term potentiation in interneurons in the amygdala. Nature 394:683-687.

Mann EO, Paulsen O (2007) Role of GABAergic inhibition in hippocampal network oscillations. Trends Neurosci 30:343-349. 
McBain CJ (2008) Differential mechanisms of transmission and plasticity at mossy fiber synapses. Prog Brain Res 169:225-240.

McMahon LL, Kauer JA (1997) Hippocampal interneurons express a novel form of synaptic plasticity. Neuron 18:295-305.

Oren I, Nissen W, Kullmann DM, Somogyi P, Lamsa KP (2009) Role of ionotropic glutamate receptors in long-term potentiation in rat hippocampal CA1 oriens-lacunosum moleculare interneurons. J Neurosci 29:939-950.

Pawelzik H, Hughes DI, Thomson AM (2002) Physiological and morphological diversity of immunocytochemically defined parvalbumin- and cholecystokinin-positive interneurones in CA1 of the adult rat hippocampus. J Comp Neurol 443:346-367.

Pelletier JG, Lacaille JC (2008) Long-term synaptic plasticity in hippocampal feedback inhibitory networks. Prog Brain Res 169:241-250.

Perez Y, Morin F, Lacaille JC (2001) A hebbian form of long-term potentiation dependent on mGluRla in hippocampal inhibitory interneurons. Proc Natl Acad Sci U S A 98:9401-9406.

Ross ST, Soltesz I (2001) Long-term plasticity in interneurons of the dentate gyrus. Proc Natl Acad Sci U S A 98:8874-8879.

Santhakumar V, Soltesz I (2004) Plasticity of interneuronal species diversity and parameter variance in neurological diseases. Trends Neurosci 27:504-510.
Sarihi A, Jiang B, Komaki A, Sohya K, Yanagawa Y, Tsumoto T (2008) Metabotropic glutamate receptor type 5-dependent long-term potentiation of excitatory synapses on fast-spiking GABAergic neurons in mouse visual cortex. J Neurosci 28:1224-1235.

Sohal VS, Zhang F, Yizhar O, Deisseroth K (2009) Parvalbumin neurons and gamma rhythms enhance cortical circuit performance. Nature 459:698-702.

Somogyi P, Freund TF, Hodgson AJ, Somogyi J, Beroukas D, Chubb IW (1985) Identified axo-axonic cells are immunoreactive for GABA in the hippocampus and visual cortex of the cat. Brain Res 332:143-149.

Tóth K, McBain CJ (1998) Afferent-specific innervation of two distinct AMPA receptor subtypes on single hippocampal interneurons. Nat Neurosci 1:572-578.

Tukker JJ, Fuentealba P, Hartwich K, Somogyi P, Klausberger T (2007) Cell type-specific tuning of hippocampal interneuron firing during gamma oscillations in vivo. J Neurosci 27:8184-8189.

Varga V, Losonczy A, Zemelman BV, Borhegyi Z, Nyiri G, Domonkos A, Hangya B, Holderith N, Magee JC, Freund TF (2009) Fast synaptic subcortical control of hippocampal circuits. Science 326:449-453.

Yazaki-Sugiyama Y, Kang S, Câteau H, Fukai T, Hensch TK (2009) Bidirectional plasticity in fast-spiking GABA circuits by visual experience. Nature 462:218-221. 